\title{
Not so rheumatic mitral stenosis
}

\section{(D) Siniša Roginić1*, (D)Krešimir Štambuk ${ }^{2}$}

'Zabok General Hospital, Zabok, Croatia

${ }^{2}$ Clinic for Cardiovascular Diseases Magdalena, Krapinske Toplice, Croatia
KEYWORDS: mitral stenosis, echocardiography, pregnancy.

CITATION: Cardiol Croat. 2018;13(5-6):205. | https://doi.org/10.15836/ccar2018.205

*ADDRESS FOR CORRESPONDENCE: Siniša Roginić, Opća bolnica Zabok, Bračak 8, HR-49210 Zabok, Croatia. / Phone: +385-98-341-234 / E-mail: sinisa.roginic@gmail.com

ORCID: Siniša Roginić, https://orcid.org/0000-0002-0384-8088 • Krešimir Štambuk, https://orcid.org/0000-0002-9107-6187

\section{|||||||||||||||||||||||||||||||||||||||||||||||||||||||||||||||||||||||||||||||||||||||||||||||||||||||||||||||||||||||||||||||||||||}

Introduction: Mitral stenosis (MS) indicates elevation of transvalvular diastolic pressure gradient which is the most often caused by rheumatic heart disease. Congenital mitral stenosis is far less common, especially in adult population..$^{1-3}$ Management of those patients is challenging due to lack of data. Clinical case: We present a case of 29 -year-old patient with known significant allegedly rheumatic mitral stenosis scheduled for percutaneous mitral balloon valvuloplasty (PMBV). After additional workup we have reclassified stenosis as moderate, caused by attachment of chordae to a single papillary muscle - defect known as a parachute mitral valve. It is the least common form of congenital MS, usually accompanied by the other left sided outflow lesions (Shone complex). Our patient had an isolated form. She was completely asymptomatic, although planning pregnancy which is hemodynamic challenge, even with a moderate MS. Patient was definitely discouraged from PMBV and referred to adult congenital heart disease center for another opinion.

Discussion: We will discuss treatment options for women of child bearing potential with congenital mitral stenosis. Congenital form of MS in adult population is a very rare disease which challenges our knowledge based mainly on managing rheumatic MS.

Conclusion: Define of etiology end severity of valvular lesion is essential, especially when invasive management is planned.
RECEIVED:

April 27, 2018

ACCEPTED:

May 10, 2018

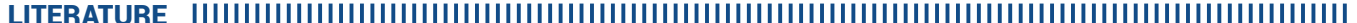

1. Toufan M, Mahmoudi SS. Isolated parachute mitral valve in a 29 years old female; a case report. J Cardiovasc Thorac Res. 2016;8(1):43-5. https://doi.org/10.15171/jcvtr.2016.08

2. Ruys TP, Roos-Hesselink JW, Hall R, Subirana-Domènech MT, Grando-Ting J, Estensen M, et al. Heart failure in pregnant women with cardiac disease: data from the ROPAC. Heart. 2014 Feb;100(3):231-8. https://doi.org/10.1136/heartjnl-2013-304888

3. Hakim FA, Kendall CB, Alharthi M, Mancina JC, Tajik JA, Mookadam F. Parachute mitral valve in adults-a systematic overview. Echocardiography. 2010 May;27(5):581-6. https://doi.org/10.1111/j.1540-8175.2009.01143.x 